University of Nebraska - Lincoln

DigitalCommons@University of Nebraska - Lincoln

\title{
Crop residue management and fertilization effects on soil organic matter and associated biological properties
}

\author{
Bingzi Zhao \\ Chinese Academy of Sciences, bzhao@issas.ac.cn \\ Jiabao Zhang \\ Chinese Academy of Sciences \\ Yueyue Yu \\ Chinese Academy of Sciences \\ Douglas Karlen \\ USDA-ARS, doug.karlen@ars.usda.gov \\ Xiying Hao \\ Agriculture and Agri-Food Canada
}

Follow this and additional works at: https://digitalcommons.unl.edu/usdaarsfacpub

Zhao, Bingzi; Zhang, Jiabao; Yu, Yueyue; Karlen, Douglas; and Hao, Xiying, "Crop residue management and fertilization effects on soil organic matter and associated biological properties" (2016). Publications from USDA-ARS / UNL Faculty. 1638.

https://digitalcommons.unl.edu/usdaarsfacpub/1638

This Article is brought to you for free and open access by the U.S. Department of Agriculture: Agricultural Research Service, Lincoln, Nebraska at DigitalCommons@University of Nebraska - Lincoln. It has been accepted for inclusion in Publications from USDA-ARS / UNL Faculty by an authorized administrator of DigitalCommons@University of Nebraska - Lincoln. 


\title{
Crop residue management and fertilization effects on soil organic matter and associated biological properties
}

\author{
Bingzi Zhao $^{1}$ - Jiabao Zhang ${ }^{1}$ Y Yueyue $\mathrm{Yu}^{1} \cdot$ Douglas L. Karlen ${ }^{2} \cdot$ Xiying Hao $^{3}$
}

Received: 28 January 2016 / Accepted: 18 May 2016/Published online: 28 May 2016

(C) Springer-Verlag Berlin Heidelberg 2016

\begin{abstract}
Returning crop residue may result in nutrient reduction in soil in the first few years. A two-year field experiment was conducted to assess whether this negative effect is alleviated by improved crop residue management (CRM). Nine treatments ( $3 \mathrm{CRM}$ and $3 \mathrm{~N}$ fertilizer rates) were used. The CRM treatments were (1) R0: $100 \%$ of the $\mathrm{N}$ using mineral fertilizer with no crop residues return; (2) R: crop residue plus mineral fertilizer as for the R0; and (3) Rc: crop residue plus $83 \%$ of the $\mathrm{N}$ using mineral and $17 \%$ manure fertilizer. Each CRM received $\mathrm{N}$ fertilizer rates at 270,360 , and $450 \mathrm{~kg} \mathrm{~N} \mathrm{ha}^{-1}$ year $^{-1}$. At the end of the experiment, soil $\mathrm{NO}_{3}-\mathrm{N}$ was reduced by $33 \%$ from the $\mathrm{R}$ relative to the $\mathrm{R} 0$ treatment, while the Rc treatment resulted in a 21 to $44 \%$ increase in occluded particulate organic $\mathrm{C}$ and $\mathrm{N}$, and $80{ }^{\circ} \mathrm{C}$ extracted dissolved organic N, 19 to $32 \%$ increase in microbial biomass $\mathrm{C}$ and protease activity, and higher monounsaturated phospholipid fatty acid (PLFA):saturated PLFA ratio from stimulating growth of indigenous bacteria when compared with the $\mathrm{R}$ treatment. Principal component analysis showed that the Biolog and PLFA profiles in the three CRM treatments were different from each other. Overall, these properties were not influenced by the used $\mathrm{N}$ fertilizer rates. Our
\end{abstract}

Responsible editor: Hailong Wang

Bingzi Zhao

bzhao@issas.ac.cn

1 State Key Laboratory of Soil and Sustainable Agriculture, Institute of Soil Science, Chinese Academy of Sciences, PO Box 821, 71 East Beijing Road, Nanjing 210008, People's Republic of China

2 USDA-ARS, National Laboratory for Agriculture and the Environment, 1015 N University Blvd., Ames, IA 50011-3120, USA

3 Agriculture and Agri-Food Canada, Lethbridge Research Centre, 5403 1st Ave S, Lethbridge T1J 4B1, AB, Canada results indicated that application of $17 \%$ of the total $\mathrm{N}$ using manure in a field with crop residues return was effective for improving potential plant $\mathrm{N}$ availability and labile soil organic matter, primarily due to a shift in the dominant microorganisms.

Keywords Soil organic matter $\cdot$ Fertilizer rate $\cdot$ Enzymatic activity $\cdot$ Biolog $\cdot$ PLFA

\section{Introduction}

Incorporation of crop residue can improve soil quality by increasing soil organic matter (Chen et al. 2006), promoting soil structure formation (Rasool et al. 2008), increasing soil microbial biomass, and enhancing various enzymatic activities (Tu et al. 2006). In addition, returning crop residues to fields rather than burning them is strongly encouraged by the government of China and environmental scientists to mitigate air pollution and improve nutrient availability in agricultural ecosystems (Chen et al. 2006; Chen et al. 2014).

Farmers are often reluctant to use crop residues because of increased labor costs and the risk for reduced crop yields. For example, in a long-term, northern China field experiment, Cai and Qin (2006) found that for the first 13 years (1990-2002), continuous application of organic compost derived from wheat (Triticum aestivum L.) residue resulted in lower crop yields than applying only chemical fertilizers without any residues. The decreased yield trend was finally reversed from 2003 onward (14 years after establishing the experiment). This response was attributed to poor synchronization between crop nutrient demand and release through mineralization of the residue (Cai and Qin 2006). Therefore, a critical factor for encouraging farmers to improve their crop residue management (CRM) practices is to shorten the poor 
synchronization period, which requires accelerating nutrient release and soil quality improvement.

Soil microorganisms drive decomposition of organic materials (Stark et al. 2008), and mineralization of organic matter through a wide range of metabolic processes (Saha et al. 2008). These processes depend primarily on the size, activity, and composition of the soil microbial biomass (Böhme et al. 2005; Tu et al. 2006), suggesting that it is critically important to build diverse soil microbial communities to sustain or improve productivity of the field with crop residues return.

Application of organic manure, such as farmyard manure from various domestic livestock, has been shown to enlarge the microbial biomass pool, promote microbial activities, and alter soil microbial communities (Böhme et al. 2005; Tu et al. 2006; Jangid et al. 2008; Zhang et al. 2012). These changes are often attributed to relatively high amounts of available organic $\mathrm{C}$ and $\mathrm{N}$, as well as indigenous microbes within the manure (Tu et al. 2006; Chu et al. 2007; Lucas et al. 2007; Blagodatskaya et al. 2009), suggesting that organic manure application may be a possible way to speed up crop residue mineralization and to avoid nutrient shortage within the first few years of the crop residue return.

Labile soil organic matter (SOM) fractions have been shown to play a central role in the transport and supply of C and $\mathrm{N}$ to microbial populations, and thus often regulate $\mathrm{N}$ mineralization (Willson et al. 2001; Cookson and Murphy 2004). Among the various indicators of soil quality (e.g., Stott et al. 2013), dissolved organic matter extracted at $25^{\circ} \mathrm{C}$ or at $80^{\circ} \mathrm{C}$, and particulate organic matter have been recognized as sensitive indicators of labile SOM pools (Dou et al. 2007; Huang et al. 2008). Although there are many studies on changes in soil microbial community and nutrient dynamics by manure and crop residues return (e.g. Zhao et al. 2013; Chen et al. 2014), few studies have documented linkages between the changes in soil nutrient availability and soil quality indicators with alterations in functioning and composition of soil microbial community in a field with crop residues return in the first few years. Moreover, it is impossible in real practice when all $\mathrm{N}$ is applied using the organic manure due to its high cost.

We hypothesized that relative to mineral fertilization alone in a field with crop residues return, a fraction of the total applied $\mathrm{N}$ using organic manure would catalyze microbial biomass growth, potentially cause a shift in microbial community composition and subsequently result in beneficial changes that would improve biological functions in the soil relative to nutrient cycling and availability. To test our hypothesis, a field experiment was conducted to: (1) assess whether returning crop residues has any negative effects on soil nutrient supply and labile SOM indicators when mineral fertilizer is applied, and if this holds true to evaluate whether this effect is alleviated by applying mineral together with some fractions of organic manure fertilizer, (2) determine whether those labile SOM indicator changes are related to (i) shifts in enzymatic activities associated with $\mathrm{C}$ and $\mathrm{N}$ cycling, (ii) microbial community substrate utilization, and/or (iii) microbial community composition, and (3) quantify how microbial community composition and labile SOM indicators are affected by the $\mathrm{N}$ fertilizer rate.

\section{Materials and methods}

\section{Field experiment}

A 2-year, four-crop field experiment was carried out in Pandian, Fengqiu County, Henan Province of China $\left(114^{\circ} 34^{\prime} \mathrm{E}, 35^{\circ} 01^{\prime} \mathrm{N}\right)$ between October 2008 and September 2010. The site has an elevation of $67.5 \mathrm{~m}$ above mean sea level and a typical monsoon climate with average annual precipitation of $597 \mathrm{~mm}$. Local topography is flat, and the soil is an Alluvic Primosols, classified as a Typic Haplustepts according to the FAO. Winter wheat (T. aestivum $\mathrm{L}$.) was grown from October to May and summer maize (Zea mays L.) was grown from June to September. A baseline soil analysis prior to initiating our study showed that the top soil $(0-20 \mathrm{~cm})$ had a $\mathrm{pH}$ of 7.9 and $7.71,0.80,0.69$, and $19.5 \mathrm{~g} \mathrm{~kg}^{-1}$ organic $\mathrm{C}$, total $\mathrm{N}$, total $\mathrm{P}$, and total $\mathrm{K}$, respectively. Soil texture is sandy loam from 0 to $60 \mathrm{~cm}$, clay from 60 to $90 \mathrm{~cm}$, and sand below $90 \mathrm{~cm}$.

In October 2008, $278 \times 5.5 \mathrm{~m}$ plots were established. Nine treatments [ 3 crop residue management (CRM) strategies $\times 3$ fertilization rates], each replicated three times (27 plots), were arranged in a randomized complete block design. The three CRM treatments were: (1) R0: for which all previous aboveground crop residues were removed and all $\mathrm{N}$ was applied using mineral fertilizer (urea); (2) R: for which all aboveground crop residue was returned after cutting it into pieces of $\leq 5 \mathrm{~cm}$ and again applying all $\mathrm{N}$ using the same mineral fertilizer as for the R0; and (3) Rc: for which all aboveground crop residues were managed as for the $\mathrm{R}$, but $\mathrm{N}$ management was changed to provide only $83 \%$ of the total $\mathrm{N}$ using mineral fertilizer and the remaining $17 \%$ using commercially available chicken manure. Supplemental $\mathrm{P}$ and $\mathrm{K}$ applications were used to maintain a constant $\mathrm{N}-\mathrm{P}_{2} \mathrm{O}_{5^{-}}$ $\mathrm{K}_{2} \mathrm{O}$ ratio of 1:0.75:0.5 as described below. When averaged for both crops, the total amount of aboveground residue returned to the soil in the $\mathrm{R}$ and $\mathrm{Rc}$ treatments was $\sim 1.57 \mathrm{~kg} \mathrm{~m}^{-2}$ year $^{-1}$ (dry weight) (i.e., $\sim 678 \mathrm{~g} \mathrm{C}$ $\mathrm{m}^{-2}$ year ${ }^{-1}$, as wheat residue contains $413 \mathrm{~g} \mathrm{C} \mathrm{kg}^{-1}$ and maize residue $450 \mathrm{~g} \mathrm{C} \mathrm{kg}^{-1}$ ). The manure contained $277.6 \mathrm{~g} \mathrm{C} \mathrm{kg}^{-1}, 22.1 \mathrm{~g} \mathrm{~N} \mathrm{~kg}^{-1}, 14.5 \mathrm{~g} \mathrm{P} \mathrm{kg}^{-1}$, and $12.4 \mathrm{~g} \mathrm{~K} \mathrm{~kg}^{-1}$. Therefore, the Rc treatment received extra $\mathrm{C}$ derived from the manure by 58,77 , and $96 \mathrm{~g} \mathrm{~m}^{-2}$ 
year $^{-1}$ for the F270, F360, and F450 treatments, see their explanations in the next paragraph respectively.

The three total $\mathrm{N}$ treatments (F270, F360 and F450) provided 270,360 , and $450 \mathrm{~kg} \mathrm{~N}^{-1}$ year $^{-1}$, split between the wheat crop which received 150,200 , and $250 \mathrm{~kg} \mathrm{~N}^{-1}$ year ${ }^{-1}$, and maize which received 120,160 , and $200 \mathrm{~kg} \mathrm{~N} \mathrm{ha}{ }^{-1}$ year $^{-1}$, respectively. Mineral $\mathrm{P}$ and $\mathrm{K}$ were applied to maintain the desired $\mathrm{N}$-based nutrient ratio for each plot. Since the manure contained only 14.5 and $12.4 \mathrm{~g} \mathrm{~kg}^{-1}$ total $\mathrm{P}$ and $\mathrm{K}$, additional mineral $\mathrm{P}$ and $\mathrm{K}$ was applied to the $\mathrm{Rc}$ plots to ensure the nutrient ratio was the same as for the $\mathrm{R}$ and R0 treatments.

Chicken manure providing $17 \%$ of the $\mathrm{N}$ was applied to the Rc plots prior to planting wheat and maize. Mineral fertilizers were applied to all plots according to local farming practices which meant that all superphosphate $(\mathrm{P}), \mathrm{K}_{2} \mathrm{SO}_{4}(\mathrm{~K})$, and either $60 \%$ (wheat) or $40 \%$ (maize) of the urea was applied as basal fertilizer and the remaining 40 or $60 \%$ of the urea was topdressed. All the plots were plowed to a depth of about $20 \mathrm{~cm}$ immediately after basal fertilization application, mixing soil, fertilizer, and crop residue as applicable.

\section{Soil sampling and analysis}

In September 2010, soil samples $(0-20 \mathrm{~cm})$ were collected from all 27 plots following harvest of the second maize crop to examine the two-year effects of our CRM and fertilizer treatments. Samples were taken randomly at six points within each plot and mixed to create a single composite sample. Each sample was then divided into two roughly equal parts. One part was air-dried and used for analysis of total organic $\mathrm{C}$ and $\mathrm{N}$ (TOC and TON), particulate organic $\mathrm{C}$ and $\mathrm{N}$ (POC and PON), occluded particulate organic $\mathrm{C}$ and $\mathrm{N}$ (OPOC and OPON), and dissolved organic $\mathrm{C}$ and $\mathrm{N}$ (DOC and DON). The other part was stored in a field-moist condition at $4{ }^{\circ} \mathrm{C}$ after sieving ( $<2 \mathrm{~mm}$ ) for up to 2 weeks awaiting analyses of soil $\mathrm{NO}_{3}-\mathrm{N}$ and microbial properties, including microbial biomass $\mathrm{C}(\mathrm{MBC})$, microbial functioning using both enzymatic activities and the Biolog ${ }^{\mathrm{TM}}$ system, as well as microbial community composition. Ultimately, all soil quality indicators were analyzed statistically and are reported on an oven-dry $\left(105^{\circ} \mathrm{C}\right)$ weight basis.

Total organic $\mathrm{C}$ and TON were determined by dichromate oxidation (Nelson and Sommers 1982) and Kjeldahl digestion (Bremner 1965), respectively. These methods were also applied to determination of POC and PON, and OPOC and OPON as indicated below. POC and PON were measured following the method of Willson et al. (2001), who defined them as the total $\mathrm{C}$ and $\mathrm{N}$ content of sand-sized (53-2000 $\mu \mathrm{m})$ soil fractions.

Separation of occluded particulate organic matter (OPOM) and free particulate organic matter (FPOM) was conducted on water stable aggregates $(53-2000 \mu \mathrm{m})$. This method was adapted from Six et al. (1998). Aggregates with 53$2000 \mu \mathrm{m}$ diameters were collected by wet sieving as described by Elliott (1986), followed by suspension in $1.85 \mathrm{~g} \mathrm{~cm}^{-3}$ sodium polytungstate. After centrifugation, the floating material (i.e., the FPOM) was aspirated. The heavy fraction was dispersed in $0.5 \%$ sodium hexametaphosphate, and passed through a $53-\mu \mathrm{m}$ sieve. Materials remaining on the sieve were used for determination of OPOC and OPON, separately. There were too few FPOM materials to measure $\mathrm{C}$ and $\mathrm{N}$ contents in the present study.

DOC and DON were extracted as described by Chodak et al. (2003) with the following modifications. Air-dried soil (20 g) was mixed with $100 \mathrm{ml}$ of $0.5 \mathrm{M} \mathrm{K}_{2} \mathrm{SO}_{4}$ at $25^{\circ} \mathrm{C}$ and $80{ }^{\circ} \mathrm{C}$ separately (under a reflux at $80{ }^{\circ} \mathrm{C}$ ) and shaken for $1 \mathrm{~h}$. After cooling, samples were extracted at $80^{\circ} \mathrm{C}$. The suspensions were centrifuged for $20 \mathrm{~min}$ at $4000 \mathrm{rpm}$ and then passed through $0.45-\mu \mathrm{m}$ filters. The DOC and DON in the filtrate were analyzed using a TOC analyzer (Muti C/N 3100, Analytik Jena AG, Germany). Results hereafter are referred to as DOC25, DON25, DOC80, and DON80, respectively, for the 25 and $80^{\circ} \mathrm{C}$ extractions, respectively.

The MBC was determined using the fumigation-extraction method of Vance et al. (1987). Fumigated and non-fumigated soils were extracted in the same manner as DOC extraction at $25{ }^{\circ} \mathrm{C}$. Total extractable $\mathrm{C}$ in the extracts was determined using the same TOC analyzer described above. A correction factor $[\mathrm{Kec}=0.38$ (Ocio and Brookes 1990)] was applied to each analysis.

Soil $\mathrm{NO}_{3}-\mathrm{N}$ was extracted with $2 \mathrm{M} \mathrm{KCl}$ using a 1:4 solidto-liquid ratio that was shaken for $1 \mathrm{~h}$ and then filtered. The $\mathrm{NO}_{3}-\mathrm{N}$ concentration in the extracting solution was determined with a Segmented Flow Analyzer (Skalar, San Plus System, The Netherlands).

Protease activity (PRO) and invertase activity (INV) were measured because PRO characterizes $\mathrm{N}$ mineralization (Saha et al. 2008), and INV can drive C cycling by catalyzing hydrolysis of sucrose (Frankenberger and Johanson 1983). The PRO was assayed by determining the tyrosine released after incubating the soil with Tris buffer and Na-caseinate at $50{ }^{\circ} \mathrm{C}$ for $2 \mathrm{~h}$, as indicated by Saha et al. (2008). Results were expressed as $\mathrm{mg}$ tyrosine released per $\mathrm{kg}$ soil per $2 \mathrm{~h}(\mathrm{mg}$ tyrosine $\mathrm{kg}^{-1} 2 \mathrm{~h}^{-1}$ ). The INV was determined using sucrose as a substrate (An et al. 2008), with the result being expressed as $\mathrm{mg}$ released glucose per $\mathrm{g}$ soil per day (mg glucose $\mathrm{g}^{-1}$ day $^{-1}$ ).

Sole carbon source utilization profiles by microbial community were generated using Biolog ${ }^{\mathrm{TM}}$ Eco-microplates. These plates contain $31 \mathrm{C}$ sources and rely on the redox dye tetrazolium violet to detect respiration from each $\mathrm{C}$ source. The method used for the inoculum preparation was adapted from Garland and Mills (1991). Each well within the microplates was directly inoculated with $150 \mu$ l of soil supernatant diluted by $10^{-3}$. The plates were incubated at $25^{\circ} \mathrm{C}$, and 
substrate utilization was monitored by measuring light absorbance at $590 \mathrm{~nm}$ every $12 \mathrm{~h}$ up to $192 \mathrm{~h}$ with an Emax precision microplate reader (Biolog Inc., Hayward, CA). Average well color development (AWCD) for metabolic activity of the microbial community was calculated as the mean of the corrected absorbance values for all $31 \mathrm{C}$ substrates. $\mathrm{AWCD}=\sum(\mathrm{Ai}-\mathrm{A} 1) / 31$, where $\mathrm{Ai}$ is color production within each well (optical density measurement), and A1 is the absorbance value of the plate's control wells.

Microbial community composition of both the original manure and soil samples was examined using phospholipid fatty acids (PLFAs) analysis. Extraction of PLFAs was carried out as described by Brant et al. (2006). Fresh soil (3 g oven-dried) was extracted for $2 \mathrm{~h}$ with $20 \mathrm{ml}$ of a chloroform-methanolphosphate buffer mixture (1:2:0.8, $\mathrm{pH} 7.0)$. The phospholipids were separated from glycolipids and neutral lipids using silica acid bonded solid-phase-extraction columns by sequential leaching with chloroform, acetone, and methanol. Phospholipids were saponified and methylated to fatty acid methyl esters (FAMEs) under $\mathrm{N}_{2}$ at $37{ }^{\circ} \mathrm{C}$ and then dissolved in hexane containing a 19:0 (methyl nonadecanoate fatty acid) FAME standard. The resulting FAMEs were analyzed with a gas chromatograph mass spectrometer (GCeMS) QP 2010 PLUS (Shimadzu, Kyoto, Japan) equipped with a Varian VF23-MS column $(30 \mathrm{~m} \times 0.25 \mathrm{~mm}$ i.d. $\times 0.25 \mathrm{~m}$ film thickness; Varian Associates Inc., Walnut Creek, CA, USA). The PLFAs 15:0, 16:0, 17:0, and 18:0 are used as biomarkers for general bacteria (Sundh et al. 1997); i15:0, a13:0, a15:0, and a17:0 for Gram-positive $\left(\mathrm{G}^{+}\right)$bacteria (Zechmeister-

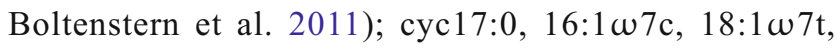
19:1 $\omega 9 \mathrm{t}, 18: 1 \omega 8 \mathrm{t}$, and 18:1 $\omega 9 \mathrm{t}$ for Gram-negative $\left(\mathrm{G}^{-}\right)$bacteria (Sundh et al. 1997; Spring et al. 2000; Zechmeister-

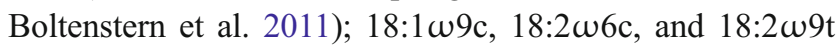
for fungi (Frostegard and Bååth 1996; ZechmeisterBoltenstern et al. 2011); and 10Me18:0 for Actinobacteria (Sundh et al. 1997; Spring et al. 2000). The PLFAs $16: 1 \omega 7 \mathrm{c}, 18: 1 \omega 7 \mathrm{t}, 19: 1 \omega 9 \mathrm{t}, 18: 1 \omega 8 \mathrm{t}, 18: 1 \omega 9 \mathrm{t}$, and $18: 1 \omega 9 \mathrm{c}$ represent monounsaturated fatty acids, while $15: 0$, 16:0, 17:0, 18:0, i15:0, a13:0, a15:0, a17:0, cyc17:0, and $10 \mathrm{Me} 18: 0$ represent saturated fatty acids. The ratio of monounsaturated PLFAs to saturated PLFAs is expressed as Mono PLFA:Sat PLFA, which can reflect biodegradability of the carbonated substrates (Bastida et al. 2008).

\section{Statistical analysis}

Univariate analysis of variance (GLM model) with two factors was used to determine the effect of crop residue management (R0, R, and Rc), N fertilizer rate (F270, F360, and F450), and the interaction between the two factors on soil quality indicators including various SOM indicators, enzymatic activities, and parameters based on Biolog and PLFA data. Tukey's Honest Significant Difference (HSD) test for multiple comparisons was run if significant differences were found $(p<0.05)$.

Absorbance values (i.e., Ai-A1) at $96 \mathrm{~h}$ in Biolog analysis as well as the concentrations of the individual PLFA were subjected to principal component analysis (PCA), separately, using a covariance matrix, to examine whether carbon source utilization profiles by microbial community and microbial community composition were shifted by CRM. The PCA axes (i.e., Biolog PC1 and PC2 for Biolog data, and PLFA PC1 and PC2 for PLFA data) that explained the largest variation in the Biolog and PLFA data were used for further analysis. Pearson correlation analysis was used to determine the significance of relationships between various SOM indicators and the functions and composition of the soil microbial community. All statistical analyses were performed using SPSS (version 17.0).

\section{Results}

\section{Labile $\mathrm{SOM}$ indicators and $\mathrm{NO}_{3}-\mathrm{N}$}

All measures of labile SOM indicators differed among the CRM treatments except DOC25, but there were no significant SOM differences $(P<0.05)$ due to fertilizer rate (Table 1). The $\mathrm{NO}_{3}-\mathrm{N}$ content was influenced by both CRM and fertilizer rate treatments. Significant interaction effect was found only for OPON; under the F270 treatment, the three CRM treatments had similar OPON content.

For the R treatment, POC, PON, and DOC 80 were 20 $30 \%$ higher, while $\mathrm{NO}_{3}-\mathrm{N}$ was $33 \%$ lower, than in the $\mathrm{R} 0$ treatment (Table 1). All other indicators showed no statistically significant differences between the $\mathrm{R}$ and $\mathrm{R} 0$ treatments. As for the Rc treatment, OPOC, OPON, DON80, and MBC were $21-44 \%$ higher, on average, than in the $\mathrm{R}$ treatment, while other labile $\mathrm{SOM}$ indicators and $\mathrm{NO}_{3}-\mathrm{N}$ levels were similar between the two treatments. The trend in $\mathrm{NO}_{3}-\mathrm{N}$ content was to decrease with decreases in the fertilizer rate.

\section{Enzymatic activities and microbial community carbon use}

Similar to most labile SOM indicators, the two enzymatic activities examined in our study were also affected by CRM treatment $(P<0.05)$, but not by fertilizer rate, nor their interaction (Table 2). No significant differences of PRO and INV were found between the R and R0 treatments. The PRO from the Rc treatment was $19 \%$ higher than from the R treatment, while the INV was similar between these two treatments.

Neither CRM treatment nor fertilizer rate had an influence on AWCD (Table 2), indicating there were no detectable differences in metabolic activity for the $31 \mathrm{C}$ substrates. Based on the overall PCA for the observed sole carbon source utilization patterns of the soil microbial community (figure not 


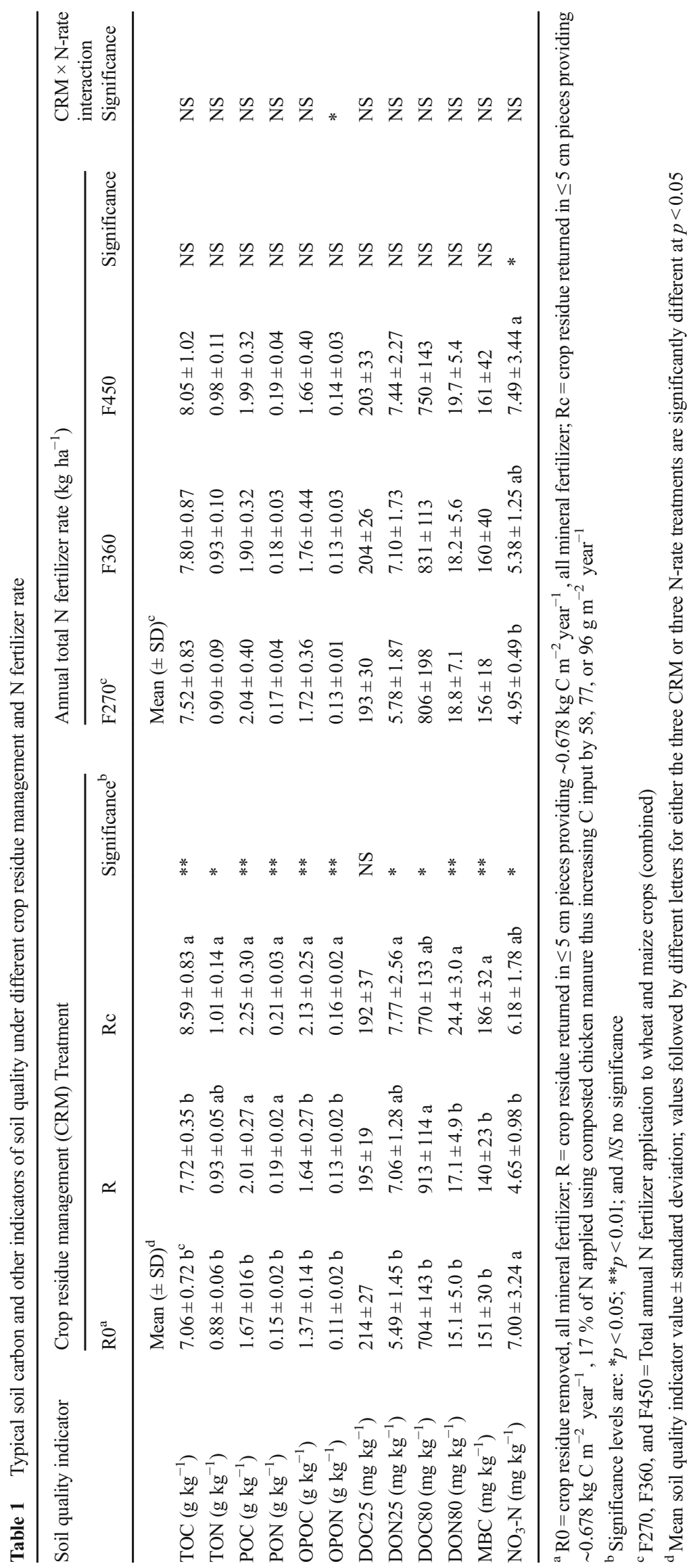




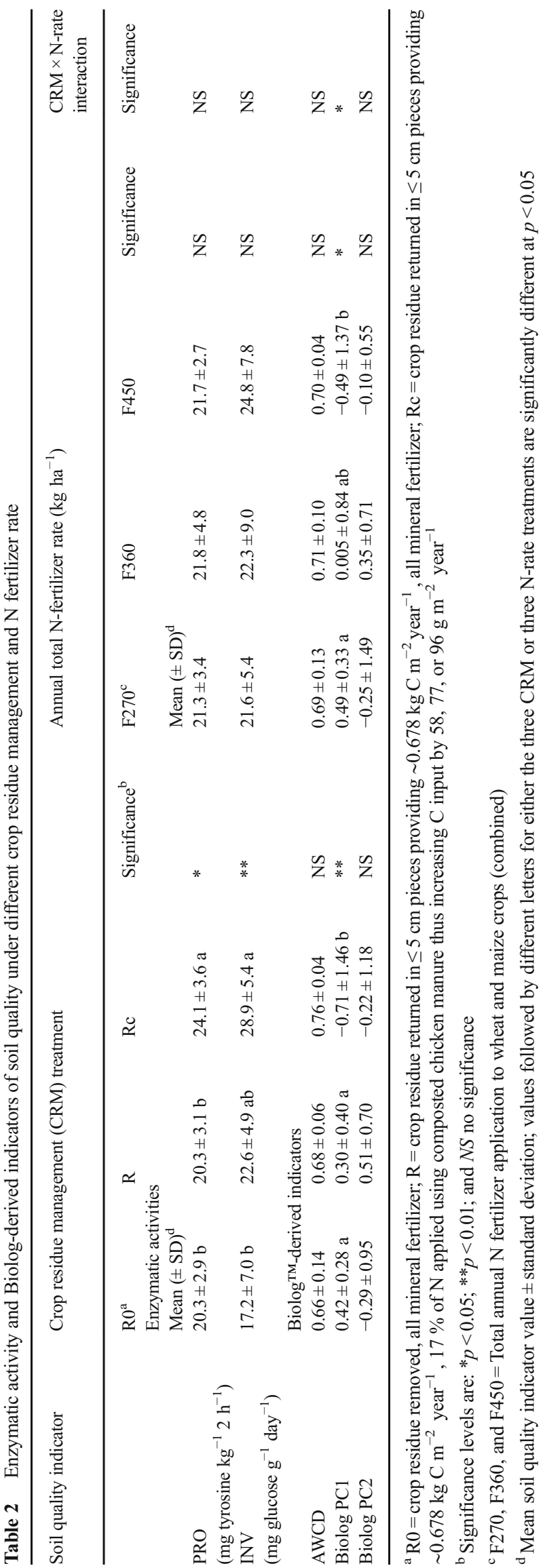

shown), the first and second principal component (i.e., Biolog PC1 and Biolog PC2) accounted for 50.7 and $9.6 \%$ of the total variance, respectively. The Biolog PC1 depended on the CRM treatment, fertilizer rate, and interaction of those factors (Table 2). The Rc treatments were different from the R treatment, as indicated by the lower values of Biolog PC1 when compared with those for the $\mathrm{R}$ and $\mathrm{R} 0$ treatments which were similar. Also, Biolog PC1 values for the F450 treatment were slightly lower than for the F270 treatment (Table 2). The Biolog PC2, however, separated neither the CRM nor fertilizer rate treatments.

\section{Soil microbial community composition}

For the microbial community composition (Table 3), CRM treatment significantly affected 15 of the 18 individual lipid biomarkers, as well as the total PLFAs. In contrast, the fertilizer rate only affected 4 of 18 individual lipid biomarkers. There was a significant interaction effect of CRM and fertilizer rate on cyc17:0, 18:1 $\omega 7 \mathrm{t}$, and 18:1 $\omega 9 \mathrm{t}$ contents. Specifically, under the Rc treatment, the cyc17:0 content in the F270 treatment was significantly higher than in the F450 treatment, and the 18:1 $\omega 7 \mathrm{t}$ and 18:1 $\omega 9 \mathrm{t}$ contents were higher in the F360 treatment than in the F450 or F270 treatments, but no significant differences were found among the fertilizer rates under the R0 and $\mathrm{R}$ treatments.

With PCA, the PLFA PC1 and PLFA PC2 axes together accounted for $57.4 \%$ of the variation (PLFA PC1 $36.5 \%$ and PLFA PC2 $20.9 \%$ ) (Fig. 1). Three clusters were identified on this factorial map due to the three CRM treatments, but none were evident due to the fertilizer rate treatments. That is, samples within each CRM treatment had microbial community profiles that were more similar to each other than to the other treatments.

The soil microbial community composition in the Rc treatment clearly differed from that of the $\mathrm{R}$ treatment along the PLFA PC1 axis (Table 3; Fig. 1). Correlation analyses showed that separation of the differences along the PLFA PC1 axis was mainly influenced by $18: 0$, i15:0,

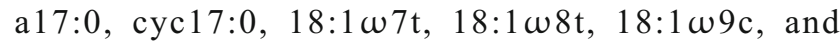
10Me18:0. The latter five PLFAs were heavily weighted along the PLFA PC1 axis and had factor loadings $>0.7$,

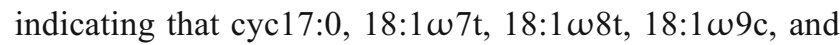
10Me18:0 were among the most important fatty acids to define the differences in the soil microbial community

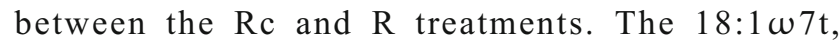
18:1 $\omega 8 \mathrm{t}, 18: 1 \omega 9 \mathrm{c}$ are monounsaturated fatty acids. They accounted for $75 \%$ of the total monounsaturated fatty acids in the Rc treatment compared to $39 \%$ in the $\mathrm{R}$ treatment. In addition, the biomarkers of $18: 1 \omega 7 \mathrm{t}$, $18: 1 \omega 8 \mathrm{t}$ existed only in the Rc treatment, whereas 18:1 $\omega 9 \mathrm{c}$ did not differ between the $\mathrm{Rc}$ and $\mathrm{R}$ treatments 
Table 3 Mean PLFA constituents (nmol g ${ }^{-1}$ ) and principal components (PLFA, PC1, and PC2) based on PLFA data in the experimental soil with various crop residue management and $\mathrm{N}$ fertilizer rate

\begin{tabular}{|c|c|c|c|c|c|c|c|c|c|}
\hline \multirow{2}{*}{$\begin{array}{l}\text { Soil quality } \\
\text { indicator }\end{array}$} & \multicolumn{4}{|c|}{ Crop residue management (CRM) treatment } & \multicolumn{4}{|c|}{ Annual total $\mathrm{N}$-fertilizer rate $\left(\mathrm{kg} \mathrm{ha}^{-1}\right)$} & \multirow{2}{*}{$\begin{array}{l}\begin{array}{l}\mathrm{CRM} \times \mathrm{N}- \\
\text { rate } \\
\text { interaction }\end{array} \\
\text { Significance }\end{array}$} \\
\hline & $\begin{array}{l}\mathrm{R} 0^{\mathrm{a}} \\
\text { Mean }( \pm \mathrm{SD})^{\mathrm{d}}\end{array}$ & $\mathrm{R}$ & Rc & Significance $^{\mathrm{b}}$ & $\begin{array}{l}\text { F270 } \\
\text { Mean }( \pm S D)^{d}\end{array}$ & F360 & F450 & Significance & \\
\hline 15:0 & $3.06 \pm 1.01 \mathrm{~b}$ & $4.94 \pm 1.55 \mathrm{a}$ & $3.53 \pm 1.24 b$ & ** & $3.61 \pm 1.30$ & $4.22 \pm 2.07$ & $3.69 \pm 0.94$ & NS & NS \\
\hline $16: 0$ & $11.5 \pm 2.2 \mathrm{~b}$ & $11.6 \pm 3.8 \mathrm{~b}$ & $14.7 \pm 1.8 \mathrm{a}$ & $*$ & $12.8 \pm 2.1$ & $11.2 \pm 3.0$ & $13.8 \pm 3.5$ & NS & NS \\
\hline $17: 0$ & $0.50 \pm 0.23$ & $0.43 \pm 0.25$ & $0.50 \pm 0.10$ & NS & $0.62 \pm 0.17 \mathrm{a}$ & $0.44 \pm 0.12 \mathrm{ab}$ & $0.36 \pm 0.22 b$ & $*$ & NS \\
\hline 18:0 & $2.13 \pm 0.46 \mathrm{c}$ & $2.77 \pm 0.57 b$ & $3.81 \pm 0.55 \mathrm{a}$ & $* *$ & $2.80 \pm 0.73$ & $2.78 \pm 0.78$ & $3.13 \pm 1.10$ & NS & NS \\
\hline General bacteria & $17.2 \pm 2.9 \mathrm{~b}$ & $19.8 \pm 3.5 \mathrm{ab}$ & $22.6 \pm 2.6 \mathrm{a}$ & ** & $19.8 \pm 2.9$ & $18.7 \pm 3.1$ & $21.0 \pm 4.7$ & NS & NS \\
\hline $\mathrm{i} 15: 0$ & $0.06 \pm 0.03 \mathrm{~b}$ & $0.06 \pm 0.03 \mathrm{~b}$ & $0.12 \pm 0.04 \mathrm{a}$ & $* *$ & $0.10 \pm 0.03$ & $0.07 \pm 0.04$ & $0.08 \pm 0.04$ & NS & NS \\
\hline a13:0 & $0.32 \pm 0.14$ & $0.31 \pm 0.14$ & $0.43 \pm 0.19$ & NS & $0.47 \pm 0.10 \mathrm{a}$ & $0.29 \pm 0.19 b$ & $0.30 \pm 0.12 b$ & * & NS \\
\hline a15:0 & $1.81 \pm 1.58$ & $2.13 \pm 0.58$ & $1.66 \pm 0.43$ & NS & $1.66 \pm 0.54$ & $2.36 \pm 1.53$ & $1.58 \pm 0.33$ & NS & NS \\
\hline a17:0 & $1.76 \pm 0.61 b$ & $3.09 \pm 0.73 \mathrm{a}$ & $3.73 \pm 0.83 \mathrm{a}$ & $* *$ & $2.64 \pm 0.79$ & $3.17 \pm 1.35$ & $2.41 \pm 0.69$ & NS & NS \\
\hline Gram-positive $(+)$ & $3.96 \pm 2.05$ & $5.60 \pm 1.30$ & $5.58 \pm 1.17$ & NS & $4.88 \pm 1.30$ & $5.89 \pm 2.33$ & $4.37 \pm 0.90$ & NS & NS \\
\hline cyc17:0 & $1.80 \pm 0.71 \mathrm{~b}$ & $2.06 \pm 0.54 \mathrm{~b}$ & $4.61 \pm 1.65 \mathrm{a}$ & $* *$ & $3.48 \pm 2.24 \mathrm{a}$ & $2.71 \pm 1.46 \mathrm{ab}$ & $2.27 \pm 0.98 \mathrm{~b}$ & $*$ & $*$ \\
\hline $16: 1 \omega 7 \mathrm{c}$ & $4.32 \pm 2.16 \mathrm{a}$ & $1.82 \pm 0.61 \mathrm{~b}$ & $2.30 \pm 0.28 \mathrm{~b}$ & ** & $2.92 \pm 1.66$ & $2.91 \pm 1.83$ & $2.60 \pm 1.70$ & NS & NS \\
\hline $18: 1 \omega 7 \mathrm{t}$ & $0.00 \pm 0.00 \mathrm{~b}$ & $0.00 \pm 0.00 \mathrm{~b}$ & $1.51 \pm 0.24 \mathrm{a}$ & ** & $0.45 \pm 0.67 \mathrm{~b}$ & $0.59 \pm 0.90 \mathrm{a}$ & $0.47 \pm 0.70 \mathrm{~b}$ & $* *$ & $* *$ \\
\hline $19: 1 \omega 9 \mathrm{t}$ & $0.00 \pm 0.00 \mathrm{~b}$ & $1.67 \pm 0.63 \mathrm{a}$ & $0.00 \pm 0.00 \mathrm{~b}$ & ** & $0.59 \pm 0.89$ & $0.71 \pm 1.14$ & $0.37 \pm 0.56$ & NS & NS \\
\hline $18: 1 \omega 8 \mathrm{t}$ & $0.00 \pm 0.00 \mathrm{~b}$ & $0.00 \pm 0.00 \mathrm{~b}$ & $4.83 \pm 1.20 \mathrm{a}$ & $* *$ & $1.38 \pm 2.07$ & $1.60 \pm 2.59$ & $1.85 \pm 2.80$ & NS & NS \\
\hline $18: 1 \omega 9 \mathrm{t}$ & $0.00 \pm 0.00 \mathrm{~b}$ & $0.00 \pm 0.00 \mathrm{~b}$ & $1.19 \pm 0.82 \mathrm{a}$ & $* *$ & $0.20 \pm 0.39 \mathrm{~b}$ & $0.52 \pm 1.02 \mathrm{a}$ & $0.17 \pm 0.32 \mathrm{~b}$ & $* *$ & $* *$ \\
\hline Gram-negative (-) & $6.11 \pm 2.80 \mathrm{~b}$ & $5.54 \pm 1.74 \mathrm{~b}$ & $14.05 \pm 1.62 \mathrm{a}$ & $* *$ & $8.99 \pm 4.49$ & $9.01 \pm 4.88$ & $7.71 \pm 4.37$ & NS & NS \\
\hline Total bacteria & $27.3 \pm 7.2 \mathrm{~b}$ & $30.9 \pm 4.0 \mathrm{~b}$ & $42.2 \pm 3.0 \mathrm{a}$ & ** & $33.7 \pm 6.9$ & $33.6 \pm 9.5$ & $33.1 \pm 8.6$ & NS & NS \\
\hline $18: 1 \omega 9 c$ & $1.86 \pm 0.62 \mathrm{~b}$ & $2.23 \pm 0.69 \mathrm{ab}$ & $3.02 \pm 0.88 \mathrm{a}$ & $*$ & $2.56 \pm 0.60$ & $2.28 \pm 1.01$ & $2.27 \pm 0.99$ & NS & NS \\
\hline $18: 2 \omega 6 \mathrm{c}$ & $1.83 \pm 0.59 \mathrm{ab}$ & $2.49 \pm 0.93 \mathrm{a}$ & $1.29 \pm 0.55 b$ & $* *$ & $1.64 \pm 0.71$ & $2.23 \pm 1.20$ & $1.74 \pm 0.41$ & NS & NS \\
\hline $18: 2 \omega 9 \mathrm{t}$ & $0.00 \pm 0.00 \mathrm{~b}$ & $4.45 \pm 0.85 \mathrm{a}$ & $0.00 \pm 0.00 \mathrm{~b}$ & ** & $1.55 \pm 2.42$ & $1.58 \pm 2.38$ & $1.32 \pm 2.00$ & NS & NS \\
\hline Fungi & $3.69 \pm 1.18 b$ & $9.18 \pm 1.90 \mathrm{a}$ & $4.31 \pm 1.28 \mathrm{~b}$ & ** & $5.75 \pm 2.93$ & $6.10 \pm 3.67$ & $5.32 \pm 2.13$ & NS & NS \\
\hline 10Me18:0 (Actinomycetes) & $1.60 \pm 0.81 \mathrm{~b}$ & $1.73 \pm 0.61 \mathrm{~b}$ & $2.98 \pm 0.81 \mathrm{a}$ & ** & $2.22 \pm 0.87$ & $2.22 \pm 1.01$ & $1.87 \pm 1.05$ & NS & NS \\
\hline Total PLFA & $32.58 \pm 8.43 \mathrm{~b}$ & $41.80 \pm 5.82 \mathrm{a}$ & $49.47 \pm 4.15 \mathrm{a}$ & $* *$ & $41.68 \pm 8.17$ & $41.91 \pm 10.66$ & $40.27 \pm 10.05$ & NS & NS \\
\hline Mono PLFA:Sat PLFA & $0.24 \pm 0.07 \mathrm{~b}$ & $0.20 \pm 0.06 \mathrm{~b}$ & $0.35 \pm 0.04 \mathrm{a}$ & ** & $0.26 \pm 0.06$ & $0.28 \pm 0.09$ & $0.25 \pm 0.10$ & NS & NS \\
\hline PLFA PC1 & $-0.65 \pm 0.44 b$ & $-0.40 \pm 0.73 b$ & $1.05 \pm 0.80 \mathrm{a}$ & ** & $0.13 \pm 0.89$ & $0.14 \pm 1.05$ & $-0.27 \pm 1.11$ & NS & NS \\
\hline PLFA PC2 & $-0.83 \pm 0.22 b$ & $1.22 \pm 0.68 \mathrm{a}$ & $-0.39 \pm 0.32 b$ & ** & $-0.02 \pm 1.09$ & $0.25 \pm 1.20$ & $-0.23 \pm 0.71$ & NS & NS \\
\hline
\end{tabular}

${ }^{\mathrm{a}} \mathrm{R} 0=$ crop residue removed, all mineral fertilizer; $\mathrm{R}=$ crop residue returned in $\leq 5 \mathrm{~cm}$ pieces providing $\sim 0.678 \mathrm{~kg} \mathrm{C} \mathrm{m}^{-2}$ year ${ }^{-1}$, all mineral fertilizer; $\mathrm{Rc}=$ crop residue returned in $\leq 5 \mathrm{~cm}$ pieces providing $\sim 0.678 \mathrm{~kg} \mathrm{C} \mathrm{m}^{-2}$ year $^{-1}, 17 \%$ of $\mathrm{N}$ applied using composted chicken manure thus increasing $\mathrm{C}$ input by 58,77 , or $96 \mathrm{~g} \mathrm{~m}^{-2}$ year $^{-1}$

${ }^{\mathrm{b}}$ Significance levels are: $*=p<0.05 ; * *=p<0.01$; and $\mathrm{NS}=$ no significance

${ }^{\mathrm{c}} \mathrm{F} 270, \mathrm{~F} 360$, and F450 = Total annual $\mathrm{N}$ fertilizer application to wheat and maize crops (combined)

${ }^{\mathrm{d}}$ Mean soil quality indicator value \pm standard deviation; values followed by different letters for either the three CRM or three $\mathrm{N}$-rate treatments are significantly different at $p<0.05$

(Table 3). This resulted in much higher $(1.75 \times)$ monounsaturated PLFA:saturated PLFA ratio in the Rc relative to the $\mathrm{R}$ treatment (Table 3 ).

\section{Relations of labile SOM indicators to microbial function and community composition}

Labile SOM indicators of OPOC, OPON, DON80, and MBC, which were shown to be significantly higher from $\mathrm{Rc}$ than from $\mathrm{R}$ treatments (Table 1), were strongly correlated with three function indicators [PRO, INV, and AWCD or Biolog PC1 $(|r|=0.584-0.951)]$, and two community composition indicators [PLFA PC1 and total PLFAs $(r=0.635-0.955)]$ (Table 4).

As for POC, PON, and DOC80, which were shown to be significantly higher from $\mathrm{R}$ than from $\mathrm{R} 0$ treatments (Table 1 ), they seemed to be less dependent on microbial properties than the aforementioned four labile SOM indicators. This was reflected by the generally good correlation with less than four microbial indicators (Table 4). POC was found to be related to INV, AWCD, PLFA PC1, and total PLFAs ( $r=0.635-0.857)$, while PON was related to INV, AWCD, Biolog PC1, and total PLFAs $(|r|=0.601-0.904)$, and DOC80 was correlated only with Biolog PC2 and PLFA PC2 (Table 4).

\section{Discussion}

\section{Effects of crop residue on soil properties}

The POC, PON, and DOC 80 were significantly higher and $\mathrm{NO}_{3}-\mathrm{N}$ content was significantly lower in soils from the $\mathrm{R}$ treatment than from the R0 treatment, but OPOC, OPON, and $\mathrm{MBC}$ were similar (Table 1). This indicates that differences in POC, PON, and DOC 80 may be primarily in the free particulate organic $\mathrm{C}$ (FPOC) and free particulate organic $\mathrm{N}$ 


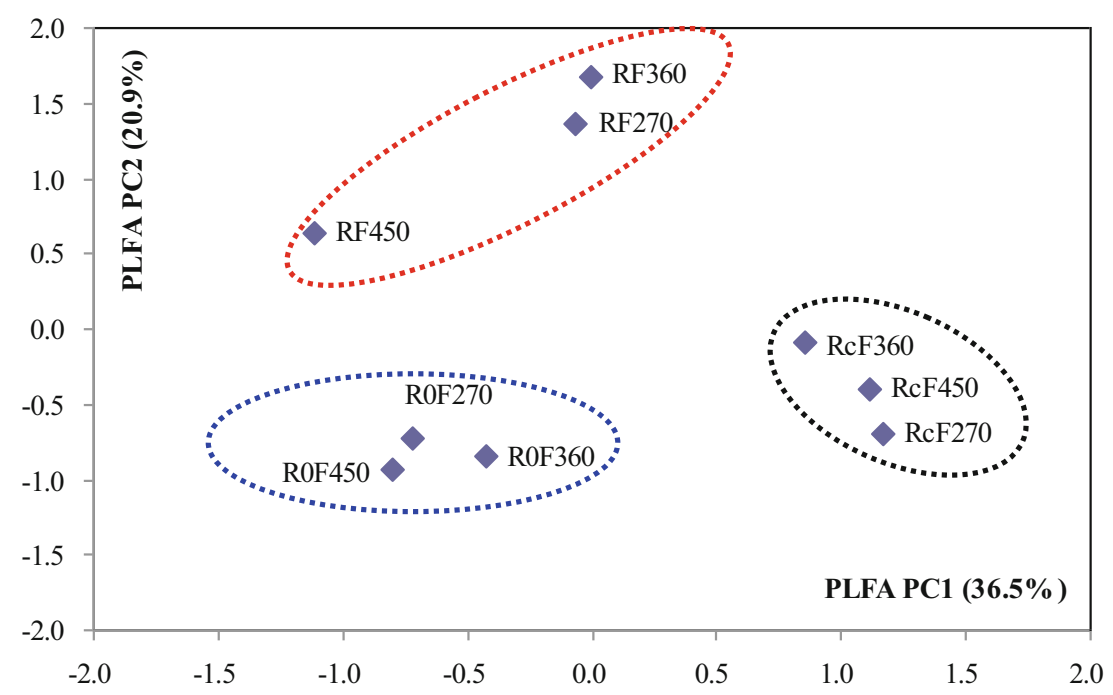

Fig. 1 A principal component analyses (PCA) combined ordination plot of phospholipid fatty acid profiles (PLFA) for the three CRM treatments (R0, R or Rc) and three $\mathrm{N}$ fertilizer rate treatments (F270, F360, or F450). The three groupings show point that are closer together than other combinations and suggest that carbon input (i.e., CRM) is more influential on the PLFA profiles than the $\mathrm{N}$ fertilizer rates. $\mathrm{R} 0=$ crop residue removed, all mineral fertilizer; $\mathrm{R}=$ crop residue returned in $\leq 5 \mathrm{~cm}$ pieces providing $\sim 0.678 \mathrm{~kg} \mathrm{C} \mathrm{m}^{-2}$ year $^{-1}$, all mineral fertilizer; $\mathrm{Rc}=$ crop residue returned in $\leq 5 \mathrm{~cm}$ pieces providing $\sim 0.678 \mathrm{~kg} \mathrm{C} \mathrm{m}^{-2}$ year $^{-1}, 17 \%$ of $\mathrm{N}$ applied using composted chicken manure thus increasing $\mathrm{C}$ input by 58,77 , or $96 \mathrm{~g} \mathrm{~m}^{-2}$ year ${ }^{-1}$; $\mathrm{F} 270$, $\mathrm{F} 360$, and $\mathrm{F} 450=$ Total annual $\mathrm{N}$ fertilizer application to wheat and maize crops (combined)

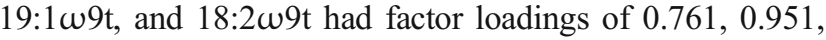
and 0.920 , respectively, while others had less than 0.7 . In addition, the distinct exceptions were that biomarkers of 19:1 $\omega 9 \mathrm{t}$ (Gram-negative bacteria) and 18:2 $\omega 9 \mathrm{t}$ (fungi) were only observed in the R treatment, and PLFA 15:0 content was significantly higher in the $\mathrm{R}$ than $\mathrm{R} 0$ treatment (Table 3 ). This suggests that 19:1 $\omega 9 \mathrm{t}, 18: 2 \omega 9 \mathrm{t}$, and 15:0 mainly contributed to crop residue decomposition.

A negative relationship between DOC 80 and $\mathrm{NO}_{3}-\mathrm{N}$ $(r=-0.749, P<0.05)$ observed in the present study was consistent with that reported by Huang et al. (2013), probably because of increased microbial $\mathrm{N}$ immobilization by bacteria. Myrold and Posavatz (2007) found that bacteria, rather than
Table 4 Correlation coefficients between labile SOM indicators and microbial indicators of soil quality in a northern China soil. The significance levels are noted as: ${ }^{\Delta} p<0.1$ or; ${ }^{*} p<0.05$

\begin{tabular}{|c|c|c|c|c|c|c|c|}
\hline & OPOC & OPON & DON80 & $\mathrm{MBC}$ & $\mathrm{POC}$ & PON & DOC 80 \\
\hline \multicolumn{8}{|c|}{ Indicators of microbial community functioning } \\
\hline \multicolumn{8}{|c|}{ Enzymatic activities } \\
\hline PRO & $0.703 * *$ & $0.649^{\Delta}$ & $0.669^{* *}$ & $0.584^{\Delta}$ & & & \\
\hline INV & $0.773 * *$ & $0.776^{* *}$ & $0.650^{\Delta}$ & $0.748^{* *}$ & $0.857 * *$ & $0.904 * *$ & \\
\hline \multicolumn{8}{|c|}{ Biolog-derived indicators } \\
\hline AWCD & $0.803 * *$ & & $0.951 * *$ & & $0.655^{\Delta}$ & $0.601^{\Delta}$ & \\
\hline Biolog PC1 & & $-0.857 * *$ & & $-0.814 * *$ & & $-0.669 * *$ & \\
\hline Biolog PC2 & & & & & & & $0.695 * *$ \\
\hline \multicolumn{8}{|c|}{ Indicators of microbial community composition } \\
\hline PLFA PC1 & $0.882 * *$ & $0.674 * *$ & $0.799 * *$ & $0.772 * *$ & $0.658^{\Delta}$ & & \\
\hline PLFA PC2 & & & & & & & $0.868^{* *}$ \\
\hline Total PLFAs & $0.955 * *$ & $0.841 * *$ & $0.740 * *$ & $0.635^{\Delta}$ & $0.821 * *$ & $0.836^{* *}$ & \\
\hline
\end{tabular}


fungi, had the greatest potential for assimilating, or immobilizing $\mathrm{NO}_{3}{ }^{-}$. In this study, we did not find any differences in the total content of bacteria between the $\mathrm{R}$ and $\mathrm{R} 0$ treatment, while some PLFAs indicative of bacteria were higher in the R than R0 treatment, such as 15:0, 18:0, a17:0, and 19:1w9t (Table 3). This may have contributed to the lower $\mathrm{NO}_{3}-\mathrm{N}$ content in the $\mathrm{R}$ than the $\mathrm{R} 0$ treatment. Therefore, mineral fertilization alone in the field with residue return tended to decrease the available $\mathrm{N}$ content.

\section{Effects of manure on soil properties in a field with crop residues return}

The most notable change between the Rc and $\mathrm{R}$ treatments was that the OPOC, OPON, DON80, and MBC were significantly higher (Table 1). Carbon in the OPOC fraction is older and more microbially derived than current input C (Six et al. 2002a), suggesting that OPOC in the Rc treatment was more likely derived from organic manure induced microbial biomass than directly from the additional $\mathrm{C}$ supplied by the manure. Larger amounts of $\mathrm{MBC}$ in the Rc treatment further support this suggestion (Table 1). The OPOC also has lower decomposition rates when compared with FPOC, and has been proven to be stable for longer periods of time and to impact soil structure stability (Six et al. 2002b). The OPOC and OPON contents were closely related $(r=0.826 ; P<0.01)$, indicating they may respond similarly to the various CRM treatments (Table 1).

Crop residue plus organic manure and crop residue alone were, respectively, the two most important sources of organic $\mathrm{N}$ in the Rc and $\mathrm{R}$ treatments. Although statistically nonsignificant (presumably due to high variability among the replicates), the difference in TON between the Rc and R treatments was $80 \mathrm{mg} \mathrm{kg}^{-1}$ (Table 1), which was much greater than the 31 to $52 \mathrm{mg} \mathrm{kg}^{-1}$ of total $\mathrm{N}$ supplied by the organic manure during the entire experimental period (i.e., 2 years). This suggests that adding organic manure to the crop residues increased the amount of soil TON derived from crop residues, presumably by stimulating the decomposition process.

One approach to confirm this proposed response would be to use the hot-water extraction method of Keeney and Bremner (1966) to determine the readily available pool of organic N. More recently, Curtin et al. (2006) reported that $\mathrm{N}$ released by hot water was mainly in organic form $(80 \%$ on average) and could better predict $\mathrm{N}$ availability for a greenhouse-grown oat (Avena sativa $\mathrm{L}$.) than total $\mathrm{N}$, anaerobically mineralizable $\mathrm{N}$, and hot $\mathrm{KCl} \mathrm{N}$. Greater DON80 in soils from Rc than $\mathrm{R}$ treatments was also observed (Table 1), suggesting that residue incorporation with a combination of mineral fertilizer plus organic manure could significantly increase potential plant $\mathrm{N}$ availability, and possibly accelerate crop residue decomposition. Therefore, the Rc treatment also had a tendency to improve soil structural stability and increase potential plant $\mathrm{N}$ availability.

The OPOC, OPON, DON80, and MBC were consistently and significantly correlated with microbial functioning and community composition measured either as PRO and INV activities or using the Biolog system (Table 4). There is a high probability that the correlation between labile SOM and microbial community composition was through microbial functioning, since microbial activity often provides a useful linkage between community composition and $\mathrm{C}$ processing (Waldrop et al. 2000). In addition, OPOC, OPON, and DON80 were also correlated with $\mathrm{MBC}(r=0.632, P<0.1$ for OPOC; $r=0.711, P<0.05$ for OPON; $r=0.545$, $P=0.129$ for DON80). This indicates that crop residues incorporation plus mineral fertilizer and organic manure $(\mathrm{Rc})$ enhanced OPOC, OPON, and DON80 levels compared to residues plus mineral fertilizer only $(\mathrm{R})$, which may be due to increased microbial community growth as well as a modification of its composition.

The higher MBC in soils from the Rc treatment than from the $\mathrm{R}$ treatment (Table 1), which reflects the size of the soil microbial community, agrees with findings reported by Saha et al. (2008) and Zhao et al. (2013), showing that MBC size increased in manure treated soil when compared to soil receiving only inorganic nutrients. It is generally recognized that increased organic residue inputs, either from plants or animal manure, will increase MBC size and enzymatic activities (Buchanan and King 1992; Dick 1992; Stark et al. 2008) because of increased availability of $\mathrm{C}$ substrate that stimulates microbial activity (Nayak et al. 2007). In this study, the Rc treatment received extra $\mathrm{C}$ derived from organic manure by 58, 77, and $96 \mathrm{~g} \mathrm{~m}^{-2}$ year $^{-1}$ for the F270, F360, and F450 treatments, respectively. The correlation of $\mathrm{MBC}$ with PLFA PC1 and total PLFAs (Table 4) was consistent with other findings that microbial diversity and $\mathrm{MBC}$ size are correlated (Bastida et al. 2008). We thus inferred that the greater MBC size from the Rc than from the R treatment was attributed to both manure-derived extra $\mathrm{C}$ and manurestimulated microbial diversity.

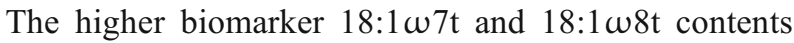
led to greater monounsaturated PLFA:saturated PLFA ratio in the $\mathrm{Rc}$ than in the $\mathrm{R}$ treatment (Table 3), indicating a greater biodegradability of the carbonated substrates in the $\mathrm{Rc}$ than the $\mathrm{R}$ treatment (Bastida et al. 2008). This suggests that Rc treatments were more capable of decomposing organic materials than the $\mathrm{R}$ treatment, which was mainly determined by the appearance of

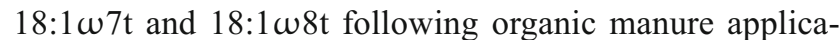
tion. The biomarkers of $18: 1 \omega 7 \mathrm{t}$ and 18:1 $\omega 8 \mathrm{t}$ were not found in the original manure (data not shown), indicating that the appearance of $18: 1 \omega 7 \mathrm{t}$ and $18: 1 \omega 8 \mathrm{t}$ in the Rc treatment rather than in the $\mathrm{R}$ treatment (Table 3) might 
not be due to direct influence of the bacteria in the compost, but due to the stimulating effect of the manure on the growth of indigenous bacteria in the soils after manure application. The results also suggest that compared to mineral fertilization alone (R), combining mineral and manure fertilizers in the Rc field induced changes in the labile SOM indicators, wherein dominant microorganisms were different.

\section{Effects of fertilizer rate on soil properties}

The fertilizer rate did not significantly affect microbial community composition (Table 3; Fig. 1), suggesting that soil microorganisms may not be sensitive to the three fertilizer rates used in this study. This is consistent with many previous reports conducted on forest soils (Lucas et al. 2007), bentgrass soils (Liu et al. 2011), and farmland soils (Chu et al. 2007). Inorganic $\mathrm{N}$ did not show any significant influence on abundance of soil microbes, nor on their composition measured by lipid analysis (Lucas et al. 2007). Using denaturing gradient gel electrophoresis (DGGE), Liu et al. (2011) found that the differences in microbial community composition occurred only between unfertilized and fertilized plots rather than between fertilizer rates after 1-year fertilization treatments, while Chu et al. (2007) reported that DGGE banding pattern was not altered regardless of soil was fertilized or not following 16year fertilization treatments.

Our results showing no significant alterations in microbial community composition due to fertilization level paralleled no changes in microbial functioning and consequently soil $\mathrm{C}$ and $\mathrm{N}$ cycling, as reflected by no significant differences in soil enzymatic activities, Biolog-derived parameters except for Biolog PC1, and all indicators for labile SOM pools among the fertilizer rates (Tables 1 and 2). The $\mathrm{F} 450$ had higher $\mathrm{NO}_{3}$ $\mathrm{N}$ content than the F360 and F270 treatments (Table 1), indicating that the highest application rate used in this study was more than the plants took up under experimental conditions.

\section{Conclusions}

Under mineral fertilization alone, returning crop residues increased soil particulate organic $\mathrm{C}$ and $\mathrm{N}$, and $80^{\circ} \mathrm{C}$ extracted dissolved organic $\mathrm{C}$ when compared with the treatment receiving no crop residues, but the soil $\mathrm{NO}_{3}-\mathrm{N}$ was significantly reduced by $33 \%$, regardless of the $\mathrm{N}$ fertilizer rate. This reduction was partly avoided by improved crop residue management (CRM), which consisted of returning crop residues and simultaneously applying $83 \%$ of the $\mathrm{N}$ using mineral fertilizer and the remaining $17 \%$ using organic manure. The improved CRM was also effective for enhancing potential plant $\mathrm{N}$ availability and labile SOM pools as documented by larger quantities of occluded particulate organic $\mathrm{C}$ and $\mathrm{N}$, and
$80{ }^{\circ} \mathrm{C}$ extracted dissolved organic $\mathrm{N}$, and bigger size of microbial biomass $\mathrm{C}$ at the end of the two-year experiment. Besides the extra $\mathrm{C}$ derived from the manure, which could fuel microbial growth and catalyze microbial activity, manure-induced microbial diversity via stimulating indigenous bacteria also contributed to the improved $\mathrm{N}$ availability and labile SOM, which was not influenced by the used $\mathrm{N}$ fertilizer rates. We infer that the improved CRM can potentially accelerate turnover rates for the returned crop residues in the soil, relative to CRM receiving crop residues combined with only mineral fertilizer.

Acknowledgments This work was supported by the National Natural Science Foundation of China (41271311), National Key Technology Support Program (2012BAD05B0203), and Science and Technology Service Network Initiative (KFJ-SW-STS-142-03, KFJ-EW-STS-083-2, KFJ-EW-STS-055-1).

\section{References}

An S, Zheng F, Zhang F, Pelt SV, Hamer U, Makeschin F (2008) Soil quality degradation processes along a deforestation chronosequence in the Ziwuling area, China. Catena 75:248-256

Bastida F, Kandeler E, Moreno JL, Ros M, García C, Hernández T (2008) Application of fresh and composted organic wastes modifies structure, size and activity of soil microbial community under semiarid climate. Appl Soil Ecol 40:318-329

Blagodatskaya EV, Blagodatsky SA, Anderson TH, Kuzyakov Y (2009) Contrasting effects of glucose, living roots and maize straw on microbial growth kinetics and substrate availability in soil. Eur J Soil Sci 60:186-197

Brant JB, Sulzman EW, Myrold DD (2006) Microbial community utilization of added carbon substrates in response to long-term carbon input manipulation. Soil Biol Biochem 38:2219-2232

Bremner JM (1965) Total nitrogen. In: Black CA, Evans DD, Ensminger LE, White JL, Clark FE, Dinauer RC (eds) Methods of soil analysis. Part 2, Chemical and microbiological properties, vol 9, Agronomy No. American Society of Agronomy, Madison, WI, pp 1149-1178

Buchanan M, King LD (1992) Seasonal fluctuations in soil microbial biomass carbon, phosphorus, and activity in no-till and reducedchemical-input maize agroecosystems. Biol Fertil Soils 13:211-217

Böhme L, Langer U, Böhme F (2005) Microbial biomass, enzyme activities and microbial community structure in two European long-term field experiments. Agric Ecosyst Environ 109:141-152

Cai ZC, Qin SW (2006) Dynamics of crop yields and soil organic carbon in a long-term fertilization experiment in the Huang-Huai-Hai Plain of China. Geoderma 136:708-715

Chen CR, Xu ZH, Mathers NJ (2004) Soil carbon pools in adjacent natural and plantation forests of subtropical Australia. Soil Sci Soc Am J 68:282-291

Chen J, Yu Z, Ouyang J, van Mensvoort MEF (2006) Factors affecting soil quality changes in the North China Plain: a case study of Quzhou County. Agric Syst 91:171-188

Chen B, Liu E, Tian Q, Yan C, Zhang Y (2014) Soil nitrogen dynamics and crop residues. A review. Agron Sustain Dev 34:429-442. doi:10.1007/s13593-014-0207-8

Chu H, Lin X, Fujii T, Morimoto S, Yagi K, Hu J, Zhang J (2007) Soil microbial biomass, dehydrogenase activity, bacterial community structure in response to long-term fertilizer management. Soil Biol Biochem 39:2971-2976 
Chodak M, Khanna P, Beese F (2003) Hot water extractable C and N in relation to microbiological properties of soils under beech forests. Biol Fertil Soils 39:123-130

Cookson WR, Murphy DV (2004) Quantifying the contribution of dissolved organic matter to soil nitrogen cycling using $15 \mathrm{~N}$ isotopic pool dilution. Soil Biol Biochem 36:2097-2100

Curtin D, Wright CE, Beare MH, McCallum FM (2006) Hot waterextractable nitrogen as an indicator of soil nitrogen availability. Soil Sci Soc Am J 70:1512-1521

Dick RP (1992) A review: long-term effects of agricultural systems on soil biochemical and microbial parameters. Agric Ecosyst Environ 40:25-36

Dou F, Wright AL, Hons FM (2007) Sensitivity of labile soil organic carbon to tillage in wheat-based cropping systems. Soil Sci Soc Am J 72:1445-1453

Elliott ET (1986) Aggregate structure and carbon, nitrogen, and phosphorus in native and cultivated soils. Soil Sci Soc Am J 50:627-633

Frankenberger WT Jr, Johanson JB (1983) Factors affecting invertase activity in soils. Plant Soil 74:313-323

Frostegard A, Bååth E (1996) The use of phospholipid fatty acid analysis to estimate bacterial and fungal biomass in soil. Biol Fertil Soils 22: $59-65$

Garland JL, Mills AL (1991) Classification and characterization of heterotrophic microbial communities on the basis of patterns of community-level sole-carbon-source utilization. Appl Environ Microbiol 57:2351-2359

Huang Z, Xu Z, Chen C (2008) Effect of mulching on labile soil organic matter pools, microbial community functional diversity and nitrogen transformations in two hardwood plantations of subtropical Australia. Appl Soil Ecol 40:229-239

Huang Z, Wan X, He Z, Yu Z, Wang M, Hu Z, Yang Y (2013) Soil microbial biomass, community composition and soil nitrogen cycling in relation to tree species in subtropical China. Soil Biol Biochem 62:68-75

Jangid K, Williams MA, Franzluebbers AJ, Sanderlin JS, Reeves JH, Jenkins MB, Endale DM, Coleman DC, Whitman WB (2008) Relative impacts of land-use, management intensity and fertilization upon soil microbial community structure in agricultural systems. Soil Biol Biochem 40:2843-2853

Keeney DR, Bremner JM (1966) Comparison and evaluation of laboratory methods of obtaining an index of soil nitrogen availability. Agron J 58:498-503

Liu Y, Dell E, Yao H, Rufty T, Shi W (2011) Microbial and soil properties in bentgrass putting greens: Impacts of nitrogen fertilization rates. Geoderma 162:215-221

Lucas RW, Casper BB, Jackson JK, Balser TC (2007) Soil microbial communities and extracellular enzyme activity in the New Jersey Pinelands. Soil Biol Biochem 39:2508-2519

Myrold DD, Posavatz NR (2007) Potential importance of bacteria and fungi in nitrate assimilation in soil. Soil Biol Biochem 39:1737-1743

Nayak DR, Babu YJ, Adhya TK (2007) Long-term application of compost influences microbial biomass and enzyme activities in a tropical Aeric Endoaquept planted to rice under flooded condition. Soil Biol Biochem 39:1897-1906

Nelson DW, Sommers LE (1982) Total carbon, organic carbon and organic matter. In: Page AL, Miller RH, Keeney DR (eds) Methods of soil analysis, Part 2. American Society of Agronomy, Madison, WI, pp 539-579
Ocio JA, Brookes PC (1990) An evaluation of methods for measuring the microbial biomass in soils following recent additions of wheat straw, and the characterization of the biomass that develops. Soil Biol Biochem 22:685-694

Rasool R, Kukal SS, Hira GS (2008) Soil organic carbon and physical properties as affected by long-term application of FYM and inorganic fertilizers in maize-wheat system. Soil Tillage Res 101:31-36

Six J, Elliott ET, Paustian K, Doran JW (1998) Aggregation and soil organic matter accumulation in cultivated and native grassland soils. Soil Sci Soc Am J 62:1367-1377

Six J, Conant RT, Paul EA, Paustian K (2002a) Stabilization mechanisms of soil organic matter: implications for C-saturation of soils. Plant Soil 241:155-176

Six J, Callewaert P, Lenders S, De Gryze S, Morris SJ, Gregorich EG, Paul EA, Paustian K (2002b) Measuring and understanding carbon storage in afforested soils by physical fractionation. Soil Sci Soc Am J 66:1981-1987

Saha S, Prakash V, Kundu S, Kumar N, Mina NK (2008) Soil enzymatic activity as affected by long term application of farm yard manure and mineral fertilizer under a rainfed soybean-wheat system in N-W Himalaya. Eur J Soil Biol 44:309-315

Spring S, Schulze R, Overmann J, Schleifer KH (2000) Identification and characterization of ecologically significant prokaryotes in the sediment of freshwater lakes: molecular and cultivation studies. FEMS Microbiol Rev 24:573-590

Stark CH, Condron LM, O'Callaghan M, Stewart A, Di HJ (2008) Differences in soil enzyme activities, microbial community structure and short-term nitrogen mineralization resulting from farm management history and organic matter amendments. Soil Biol Biochem 40:1352-1363

Stott DE, Karlen DL, Cambardella CA, Harmel RD (2013) A soil quality and metabolic activity assessment after 57 years of agricultural management. Soil Sci Soc Am J 77:903-913

Sundh I, Nilsson M, Borga P (1997) Variation in microbial community structure in two boreal peatlands as determined by analysis of phospholipid fatty acid profiles. Appl Environ Microbiol 63:1476-1482

Tu C, Ristaino JB, Hu S (2006) Soil microbial biomass and activity in organic tomato farming system: effects of organic inputs and straw mulching. Soil Biol Biochem 38:247-266

Vance ED, Brookes PC, Jenkinson DS (1987) An extraction method for measuring microbial biomass C. Soil Biol Biochem 19:703-707

Waldrop MP, Balser TC, Firestone MK (2000) Linking microbial community composition to function in a tropical soil. Soil Biol Biochem 32:1837-1846

Willson TC, Paul EA, Harwood RR (2001) Biologically active soil organic matter fractions in sustainable cropping systems. Appl Soil Ecol 16:63-76

Zechmeister-Boltenstern S, Michel K, Pfeffer M (2011) Soil microbial community structure in European forests in relation to forest type and atmospheric nitrogen deposition. Plant Soil 343:37-50

Zhang QC, Shamsi IH, Xu DT, Wang GH, Lin XY, Jilani G, Hussain N, Chaudhry AN (2012) Chemical fertilizer and organic manure inputs in soil exhibit a vice versa pattern of microbial community structure. Appl Soil Ecol 57:1-8

Zhao B, Chen J, Zhang J, Xin X, Hao X (2013) How different long-term fertilization strategies influence crop yield and soil properties in a maize field in the North China Plain. J Plant Nutr Soil Sci 176:99-1 